4-30-2015

\title{
A Double Dispossession: The Crimean Tatars After Russia's Ukrainian War
}

Stephen Blank

American Foreign Policy Council

Follow this and additional works at: https://digitalcommons.usf.edu/gsp

\section{Recommended Citation}

Blank, Stephen (2015) "A Double Dispossession: The Crimean Tatars After Russia's Ukrainian War," Genocide Studies and Prevention: An International Journal: Vol. 9: Iss. 1: 18-32.

DOI:

http://dx.doi.org/10.5038/1911-9933.9.1.1271

Available at: https://digitalcommons.usf.edu/gsp/vol9/iss1/5

This Articles is brought to you for free and open access by the Open Access Journals at Digital Commons @ University of South Florida. It has been accepted for inclusion in Genocide Studies and Prevention: An International Journal by an authorized editor of Digital Commons @ University of South Florida. For more information, please contact digitalcommons@usf.edu. 


\title{
A Double Dispossession: The Crimean Tatars After Russia's Ukrainian War
}

\author{
Stephen Blank \\ American Foreign Policy Council \\ Washington, D.C., USA
}

\begin{abstract}
Genocide and genocidal political processes have been used by the Russian state for decades-if not centuries-as a technique of self-colonial rule intended to eliminate "dissident" ethnic identities. Within this context, the historical fate of the Crimean Tatars is surely a unique one. Despite Soviet obstructions, the Crimean Tatars eventually returned to their homeland in Crimea after suffering forced deportations and genocide at the hands of the Soviet government. Now, 70 years after their deportation and genocide by Stalin, the Crimean Tatars are still fighting for justice. Defined as an autonomous group in their own land under the Ukrainian government, the Tatars found themselves in an even more precarious position when they were forcibly transplanted back into Putin's Russia after the 2014 Russian annexation of Crimea. In a Russian state that continues to resort to the deportation and the repression of "dissident" or otherwise politically suspect ethnic minorities, Crimean Tatars risk not only new repressions and injustices but a continuation of genocidal political and social repression.
\end{abstract}

Keywords: Crimean Tatars, Crimea, Russia, Ukraine, genocide, foreign policy, Ukrainian War

Norman Naimark, "Ethnic Cleansing and even genocide remain a dangerous possibility."1

Bertolt Brecht, "and the bitch that bore him is still in heat" -The Resistible Rise of Arturo Ui

These two quotations highlight for us the ensuing drama of what can only be called the second or double dispossession of the Crimean Tatars. The Tatars' historical fate is surely a unique one. Having returned to their homeland in Crimea despite Soviet obstruction, and still fighting for justice, defined by autonomy on their own land under the new Ukrainian government 70 years after their deportation and genocide by Stalin, the Tatars have now found themselves forcibly transplanted back into Putin's Russia. As the two quotes above suggest, the forces that made for their first deportation and genocide after a century and a half of encroaching Russian dispossession after 1783 are still very alive. Indeed, those forces dominate today's Russia. Consequently the Crimean Tatars risk not only new repressions and injustices but also a second or double dispossession, as Naimark suggests above. And they are probably not alone in being at risk given the Russian state chauvinism and repression that characterize today's Russia.

This is not an excessively inflamed assessment. Neither is Naimark the only Western observer who warns that this outcome is again possible. Carol Weaver has also written that, "the Black Sea region is still an area where people are afraid of invasion, ethnic cleansing, and general oppression." ${ }^{2}$ The forces that made for the first dispossession, Russian autocracy, imperial mythology, greed, xenophobia against Muslims, and national security concerns are still quite alive in Putin's Russia. Indeed, they are currently thriving. A careful examination of contemporary Russian politics quickly reveals that the Putin regime has decisively opted to restore something akin to Nicholas I's "official nationality," an ideological formation that glorifies the Tsar (in this case Putin) and Russian autocracy, the dominant role of the Russian Orthodox Church and the glorification of the Russian nationality and culture, against what is supposed to be a decadent but also encroaching and hostile West. ${ }^{3}$ Under that kind of regime no ethno-religious minority-especially one where Moscow has an acute consciousness of its previous guilt in the first genocide of 1944, and where the Tatar minority itself continues to assert its demands for historical (and economic) justicecan be said to have favorable opportunities for asserting its consciousness and for redressing historical crimes. Indeed, much evidence already shows that the Tatars' demands for autonomynot separatism - are already being repressed along with their other human rights. ${ }^{4}$ Thus they are already being subjected to systematic oppression and disenfranchisement, necessary though not sufficient stages on the road to ethnic cleansing and genocide. ${ }^{5}$ And we have already seen that. ${ }^{6}$ The evidence below shows that it is quite possible that they may not only not get their land back from 
Putin's Russia but even lose it again. At the same time, Russian history since the inception of the Russian state up to the present, suggests that deportation and worse still remain options available to the rulers of Russia.

\section{Dispossession, Genocide, and Russian Statecraft}

Indeed, throughout Russian history deportation has been a "constant operating factor" in Russian statecraft, beginning with Ivan III's takeover of Novgorod in 1478 after which he promptly deported the entire population. Since then, mass deportations have remained part of Russia's "instrumentarium" of approaches to ethnic or other minorities deemed insufficiently loyal. Scholars such as Norman Naimark have demonstrated clearly that ethnic cleansing - indeed, genocidehas been used as a instrument for consolidating power in the Russian state, through the Tsarist regimes, through Stalin's time, and to the present. ${ }^{7}$ These examples throughout Russia's history reveal similarities in tactics and strategies with later practices, such as mass deportations to Siberia, or into serfdom, or in the case of the Circassians to Turkey in 1863, up through Stalin's genocidal campaigns to the recent Chechen war and beyond. ${ }^{8}$

As the nineteenth century ended and the twentieth century began, the Russian state continued to use mass deportations - which were always accompanied by mass death - as a way of consolidating power in the Russian empire. This process has been termed "self colonialism" by many observers, and created a situation where the ethnic identity of national minorities was interpreted as a form of dissent and a political impediment against state power. This violent repression and removal of national minorities in the Tsarist, and later the Soviet state, was the historical and political context that gave rise to the concept of genocide. ${ }^{9}$ Raphael Lemkin, who was born in Imperial Russia and an expert on Soviet criminal law, coined the word genocide between 1942 and 1943, but he developed much of the theoretical concept of genocide during his work with the League of Nations in the 1930s when he attempted to outlaw state terror that was intended to destroy national minorities physically and culturally and remove them from a given society. ${ }^{10}$ As Terry Martin has found, "between 1935 and 1938, at least nine Soviet nationalitiesPoles, Germans, Finns, Estonians, Latvians, Koreans, Chinese, Kurds, Iranians - were all subjected to ethnic cleansing." ${ }^{\prime 11}$ Indeed, he found that territorial resettlement of suspect socio- political groups began in the 1920s and was then based on Marxist-Leninist categories of social class only to mutate in the 1930 s to a form of what amounted to ethnic cleansing. ${ }^{12}$ Furthermore, Martin also commented that, "therefore, as with most cases of ethnic cleansing, the Soviet practice included substantial levels of intentional murder." ${ }^{13}$

Lemkin defined genocide as "a coordinated plan ... aiming at the destruction of essential foundations of the life of national groups, with the aim of annihilating the groups themselves." Lemkin explicitly referred to genocide as a form of colonial practice with two phases: "One, the destruction of the national pattern of the oppressed group; the other, the imposition of the national pattern of the oppressor."14 While common definitions of genocide are often very different, this definition of genocide is useful for understanding the long-standing logic of Russian statecraft and the current situation of the Tatar people. Scholars who use Lemkin's definition of genocide not only see genocide as a form of colonization or self-colonization, but a technique of state power intended to destroy ethnic identities and create new ones within a society, to reorganize relationships within a society to fit the political needs of the regime in power-through mass killings, but also through acts such as terror, deportation, severe repression, the abduction of children, and so forth. ${ }^{15}$

With this historical understanding of genocide, as a technique of self-colonial rule intended to eliminate "dissident" ethnic identities, it becomes apparent that genocide is a long-standing aspect of the practices and policies of the Russian state. In this context some may also cite as genocide, or genocidal, the huge fall in Chechnya's population since 1994 as either an intended example or unforeseen by-product of the Chechen wars after 1994. Indeed, Naimark suggests on the basis of Russian evidence that the Chechen wars since 1994 led to the official reconsideration of programs of mass deportation for the Chechens:

Serious evidence indicates that the Russian government developed plans to deport the Chechens once again in the mid-1990s if they had lost the war. During the outbreak of the 
1999 war, the Chechens seemed unwilling to accept the borders cut out for them after their return (from deportation by Stalin-author) in the 1950s; thus they carried the fighting into Dagestan. But again evidence has turned up indicating that the huge number of Chechen refugees in Ingushetia may be sent off to the Altai region, a solution presumably not of the Chechens' own choosing. There have also been episodic suggestions in the Russian press to disperse the Chechens throughout the Siberian north and east. Ethnic cleansing and even genocide remain a dangerous possibility. ${ }^{16}$

In our own time,

In the fall of 2006, Russian officials rounded up more than 2,300 Georgians and deported hundreds of them in cargo planes. The operation, which hit amidst an embargo on Georgian wine, water and fruit and vegetables, was largely seen as retaliation against former Georgian President Mikheil Saakashvili's administration for detaining and deporting four Russian military officers on espionage charges. Georgia filed a complaint against Russia in Europe's senior human-rights court in 2007, but it took nearly seven years for the ECHR to pass a verdict. "The Russian authorities had implemented a coordinated policy of arresting, detaining and expelling Georgians nationals" violating international law that bars the "collective expulsion of aliens" and "inhuman and degrading treatment," the ECHR said in a press release on the July 3 verdict.

The continuing resort to deportation of "dissident" or otherwise politically suspect ethnic minorities underlines the continuity of the present regime with its Tsarist and Soviet predecessors. Thus it is clear that as long as the Russian state remains an updated version of the patrimonial Muscovite Tsarist regime as it is today no ethnic, religious, or other minority of any kind in Russia is safe, and none of them can repose any confidence in Russian guarantees and promises for Ukraine if not earlier examples have shown the value of such guarantees. ${ }^{18} \mathrm{~A}$ regime that can coldly consider and countenance the deportation of masses of its citizens offers no safe harbour to any one of its subjects. Neither can we truly call the subjects of this state genuine citizens in situations where the most basic human rights count for nothing and can be abrogated at a moment's notice on a whim.

Moreover, although war may be the ultimate argument of kings (ultima ratio regum); violence as such is seen by some scholars as the alpha and omega of the state. Thus Russia also can be envisioned as what North, Weingast, and Wallis call a "limited access state." 19 Such orders are based on personal or personalized norms of rule are weakly developed in regard to social organizations and cannot therefore rely on third-person enforcement of legal norms or contracts. Long-term economic growth in such states approaches zero meaning that for every period of growth there is one of decline in per capita income. The deficiencies of such orders with respect to forming impersonal and binding institutions also mean that they are much more permeated by violence unless potentially violent elements are bought off by rents. As the authors note,

Systematic rent-creation through limited access [to assets-author] in a natural state is not simply a method of lining the pockets of the dominant coalition; it is the essential means of controlling violence. Rent creation, limits on competition and access to organizations are central to the nature of the sate, its institutions, and the society's performance. Limiting the ability to form contractual organizations only to members of the coalition ties the interests of powerful elites directly to the survival of the coalition, thus ensuring their continued cooperation with the coalition. ${ }^{20}$

Consequently "war is the health of the state." Violence is inherent in the nature of the state. And the desire of Russian elites to possess the assets and lands of Crimea that hold a privileged place in the mythology of Russian imperialism was a powerful motive for the first dispossession of the Crimean Tatars, beginning from Catherine the Great's takeover of the area in 1783. Although the main motives for the current occupation were probably political rather than economic, Moscow's 
unseemly haste in trying to annex Crimea and deny those fields to Ukraine indicates the Russian elite's alertness to the seizure of economic assets here, and their denial of those assets to those living in Crimea. ${ }^{21}$

Thus the very nature of the state as such offers another necessary precondition for concern about the Tatars' future. Alternatively one could argue, as do Daron Acemoglu and James Robinson, that political decisions determine the nature of any country's economic institutions and that in Russia's case governments have historically decided for extractive rather than inclusive economic and political institutions. ${ }^{22}$ Further adding to these authors' argument we can bring in the insight, brilliantly expressed by Alexander Etkind, based on Kliuchevsky's observation that Russia's history is one of self- or internal colonization. Russian rulers related and, as Etkind observes, still relate to their subjects as if they were the masters of a colonial government ruling over subjects who were both alien to them and not to be regarded as autonomous human beings. Furthermore, borrowing Hannah Arendt's term of "imperial boomerang," he notes that the practices of colonial administration employed by these rulers in Russia's peripheries were often particularly brutal, corrupt, and then imported back into Russia's heartland, bringing tragic and systematic misrule to Russia's heartlands. ${ }^{23}$ The deportation of ethnic minorities practiced by Stalin comes close to the apogee of such brutal colonial practices. But Naimark and Weaver's warning and the nature of the Russian state today suggests that less catastrophic though still brutally repressive measures are still the order of the day in Putin's Russia.

\section{A Return to Fascism and the Consequences for a Tatar Ethnic Minority}

At the same time, and equally alarmingly, apart from its resemblances to past Russian autocracies, Putin's Russia increasingly resembles a fascist system like those of Mediterranean fascist regimes from Mussolini, Vichy France, Franco's Spain and Salazar's Portugal to the Colonels' Greece of 1967-74, all of which were intrinsically notoriously hostile to the claims of minorities. Vichy France's slogan of Travail, Famille, and Patrie could easily apply to authoritarian Russian regimes as Maurice Friedberg did to Brezhnev's Russia and could be quite appropriate to Putin's Russia. ${ }^{24}$ And this framework is intrinsically hostile to the claims of ethno-religious minorities. Already several years ago Pierre Hassner observed that Putin "had led Russia into a harsh brand of authoritarianism with Fascist features." ${ }^{25}$ Hassner went on to discern the advent of fascism in the elimination of rival power centers, the cult of Putin, the creation of official youth groups in support of the regime to conduct, among other things the bullying of ethnic minorities, xenophobia, and the cult of Stalin. ${ }^{26}$

Hassner is not alone in his observations as these phenomena have, if anything, become stronger over time. ${ }^{27}$ Like other fascist states in history, Russia has lost meaningful parliaments, independent judiciaries, and viable political parties and elections ${ }^{28}$ Under Putin, fascist hypernationalism has created a second situation that is also common to fascist regimes through history, especially unconsolidated fascist regimes, where ethnic Russian nationals in neighboring countries are called upon as potential fifth columns that appeal to Russia for brotherly assistance and whom Russia calls upon in defense of the motherland..$^{29}$ Indeed to the extent that the current regime increasingly resembles those of the past, not lest Stalin's, it clearly partakes of similar attributes, like the glorification of Russian culture and of the autocrat. And insightful observers like Joseph Schumpeter already realized that it was converging on fascism already in the 1940s when the initial Stalinist deportations of Crimean Tatars occurred. ${ }^{30}$

Beginning in the spring of 1944, the People's Commissariat of Internal Affairs arrested en mass Tatar Muslims in Crimea on the charge of conspiring with Hitler during WWII. ${ }^{31}$ Over 180,000 Crimean Tatars were deported to various parts of the USSR in overcrowded cattle trains, where they died of starvation, disease, and exposure to the cold. They starved to death in labor camps, collective farms, or forced-labor factories. Within two years, just under half of the exiled Tatars were dead, and the Crimean population decimated. The deportations were explicitly intended to remove a national minority from Crimea that was resisting Stalinist rule, in order to bring Crimea territory under the control of Moscow, while spreading the surviving Tatars across the USSR to force their ethnic assimilation and the ensure the destruction of their "troublesome" ethno-national group. $^{32}$ 
Over the last half a century, the Crimean Tatars have slowly begun to demand justice and restitution. This mobilization was aided with the break up of the Soviet Union, when Crimea became part of an independent Ukraine. With the Russian invasion of Ukraine in 2014, and the annexation of Crimea in March, Putin inherited a Tatar population in Crimea that believed the Russian state had committed war crimes and genocide against them, and had been demanding justice. Beyond these factors of historical Russia autocracy, imperialism, and chauvinism - which are all preconditions of ethnic animosity and regime suspicion over the Tatars' claim for justicethere are at least two other major considerations why the Crimean Tatars and other minorities, like Muslims in the North Caucasus, are again at risk in Putin's neo-Tsarist, if not neo-Soviet, or even Fascist Russia. First, Putin and his team have evidently concluded that Russia can only be governed and secure if it is an empire, a conclusion entailing the destruction of its neighbors' sovereignty and integrity. In such a form, Russia can only survive as a militarizing or militarized fascist-like state, in a condition of permanent conflict with its neighbors and interlocutors. This is because the state of war that Russia is inciting in world affairs is the external manifestation of its governing logic of empire that necessarily implies an equal state of internal war against all forms of dissent, ethnic or otherwise, inside Russia. Under such conditions the existence of a vocal ethnic minority -in a strategically sensitive area, and one that has connections with foreign governments -immediately falls under intensified state suspicion and scrutiny.

Obviously the belief that Russia can only survive as an empire at others' expense means war or at least permanent conflict both at home and abroad, especially given the nature of the Russian state. Apart from being a facsimile of similar Hitler speeches, Putin's speech to the Duma on March 18,2014 , also constituted a landmine against the sovereignty of every state from Poland to Central Asia. ${ }^{33}$ Putin here reiterated the right to send the Russian army abroad to defend Russian "citizens," demonstrating conclusively that Russia respects neither these governments' sovereignty nor their territorial integrity and is prepared to destroy both in the name of its great power interests. ${ }^{34}$ And his subsequent call for self-determination of Russians abroad while repressing self-determination at home reiterated that point. ${ }^{35}$ Certainly that latter call, especially when Russians believe that Crimea is "predestined" to be part of a revived Russian empire, or has "always been" Russian land, strongly militates against any forbearance for the Crimean Tatars or for other minorities within the Russian Federation. Moreover, the prohibition on domestic calls for self-determination means that any advocacy by the Crimean Tatars for their rights that include even rights short of selfdetermination stands at risk of being criminalized and subjecting its authors to harsh repression. ${ }^{36}$

The foregoing autocratic, repressive, even militarized nature of the state are all preconditions for repression of any future Tatar demands for justice, whatever forms they might take. But what adds to the dangers facing the Crimean Tatars is the foreign policy aspect of their situation, living in and around a strategic area that is undergoing conflict if not war, and having foreign contacts in a major state, Turkey. As history, especially in the Balkans and Black Sea area, suggests these factors powerfully reinforce ethnic suspicion by governments towards ethnic or religious minorities, and for state-sponsored or organized violence against them. ${ }^{37}$ In addition to these points the struggle over regional security issues in "the former Soviet sphere" are among the most intractable conflicts between Russia and the West in contemporary international relations. Thus the prominent Russian analyst, Sergei Karaganov, Director of the prestigious Council on Defense and Foreign Policy (SVOP), reportedly told a conference in Germany in 2009 that the "core of all differences between the West and Russia is the question of whose sphere of influence the Soviet successor states fall into." 38

In this context both historians and political scientists have focused on the connection between exogenous geopolitical conditions and rivalries on the one hand, and the internal dynamics of the formation of ethno-religious and nationalist movements throughout the Black Sea region as interactive processes that give rise to ethnic strife and conflict. If one adds to this mix the vicissitudes of post-Soviet state-building in the former Soviet republics, a process that clearly has not run its course, it becomes clear that considerations of security will exercise a profound importance in framing Russian policy and relations towards groups like the Crimean Tatars. ${ }^{39}$ In the contemporary Black Sea region this interaction is likely to be particularly stressful on all concerned because the region actually functions as a kind of laboratory for the study of the so-called "new wars." ${ }^{10}$ Yet 
at the same time it also serves as a laboratory for the tensions between Russia and its Western interlocutors over a vast agenda including the resolution of ethnopolitical conflicts in the former Soviet Union, energy rivalries, the modalities of international intervention, and missile defense. Neither does this list exhaust all the issues at stake in the East-West agenda.

Given the importance of "national security" for many actors in the overall Black Sea region and the close links between ethno-national development, the tensions of state building, and international geopolitical rivalries it is not surprising that some mélange of these considerations have figured in past Russian and Turkish examples of ethnic cleansing, deportation, and even genocide. Indeed, as Michael Reynolds and Terry Martin, to name only two scholars, have found, the construction of a multinational state in both Tsarist and Soviet Russia and the Young Turks' Turkey intimately connected ethnic to foreign policy issues. ${ }^{41}$ As Martin observes,

It was the Soviet leadership's strong commitment to forming a multinational state, rather than any hostility to ethnic identities, that politicized ethnicity by linking it to the formation of administrative territories, land possession, and resettlement. This domestic nationalities policy was then further linked to Soviet foreign policy goals. In order to explore this linkage, I will introduce two further Bolshevik concepts-Soviet xenophobia and the Piedmont Principle and show how they led to the formation of a novel Soviet administrative territory: the border regions. By Soviet xenophobia, I mean simply the exaggerated Soviet fear of foreign influence and foreign contamination. I absolutely do not mean traditional Russian xenophobia. Soviet xenophobia was ideological, not ethnic. It was spurred by an ideological hatred and suspicion of foreign capitalist governments, not the national hatred of nonRussians. Foreign intervention during the civil war did not create Soviet xenophobia. It merely confirmed a pre-existing ideological inclination. Soviet xenophobia was, however, given a national focus by ongoing low-intensity guerrilla warfare and sporadic partisan uprisings along the entire Soviet frontier. Whereas foreign military intervention had been brief and discrete, guerrilla warfare involved ongoing secretive border crossings and relied on an ambiguous combination of foreign and domestic support. ${ }^{42}$

We can, in fact, point to "lessons learned" from the history of the overall area as its states and people have increasingly become independent political actors in world history or have striven to achieve that status. Historians and political scientists alike have recently re-emphasized the fact that the idea of establishing a congruence between ethnic and political boundaries that is a distinguishing feature of nationalism wherever it occurs came to the Black Sea and Eastern Europe from the West. Therefore the impetus towards ethnic and political homogenization that characterizes regimes across Eastern Europe and not just Russia has a powerful European strategicpolitical logic behind it. ${ }^{43}$

In the case of the Crimean Tatars, the special connection between them and Turkey-to which many Tatars have fled over the centuries from Russian misrule and oppression - has only enhanced their condition of being regarded as a potentially alien ethno-religious "fifth column" in Crimea. In the Soviet Union and in contemporary Russia where every conceivable issue has been or is being "securitized," this state of being regarded ab initio as a suspect people who oppose the annexation of Crimea puts the Tatars at enhanced risk in conditions of intensified geopolitical rivalry between Russia and Turkey, or between Russia and the West as now appears to be taking shape. This securitization process typifies the Putin regime's approach to Russian national security issues because it is all-embracing. As Sergei Rogov, Director of the USA and Canada Institute, observed, "Over here, when the Russian Federation's Security Council was set up, we adopted an all-embracing definition of security that stipulated the security of the individual, society, and state from external and internal threats in all spheres of vital activity." 44

And this process, in the absence of democratic reform to establish true democratic controls over the security sector has allowed the military and the government to extend the securitization process and ultimately allowed the military to concern itself with defining non-military as well as military threats. Political actors who first politicize an issue as a threat to security and then securitize it aim to persuade relevant audiences, in this case, the political and military elite, that the 
issue in question poses an "existential threat to the country, either to its territory, the integrity of the state, its group identity, its environment, or its economic interests." ${ }^{45}$

Securitization thus denotes political actors' efforts, most often, though not exclusively, through speech or discourse, to take an issue out of normal politics and bring it into the realm of security. This process subordinates the issue to the competence of security organs, removes it from the public realm, substitutes secret bureaucratic decisions for open politics, and often contravenes human or civil rights. ${ }^{46}$

The aim of a "securitizing move" is typically to enable "emergency measures" that can secure the survival of a referent object. If and when the content of the security "speech act" is acknowledged as legitimate by a (significant) "audience" the issue in question has become successfully "securitized." It has been moved out of the sphere of "normal politics" and into the sphere of "emergency politics;" where it can be dealt with in an urgent manner and with fewer formal and informal restrains. ${ }^{47}$

Actors make "securitizing moves" not just to place an item on the agenda, but also to claim that their agency alone has the capability either to define or resolve the problem or to implement the appropriate solution. And as Reynolds and Martin suggest, the Crimean Tatars, among others have been the victim of such an outlook in Soviet times when ethnic minority communities on the border or in strategic areas came under suspicion from Moscow because of their connections abroad or proximity to key foreign areas, in this case the Black Sea. ${ }^{48}$ Indeed, as Naimark points out the deportations in the Crimea of 1944 that caught the Tatars in their dragnet were aimed at deporting every non-Slavic group in the area, perhaps as Reynolds suggests, in anticipation of Stalin's subsequent geopolitical demands upon Turkey. Indeed, Stalin apparently aimed at obliterating those Crimean nationalities' living memory, culture, and history. ${ }^{49}$

This confluence of the nature of governance of the Russian state with geostrategic imperatives places the Crimean Tatars at increased risk. Historically and today, especially in the Russian empire where they lived until 1991 and where they are once again forcibly enclosed, the Crimean Tatars may be defined as a "non-core group" (ethno-religious or ethnic minority) that possess an external connection or involvement, particularly with Turkey. Accordingly Harris Mylonas argues that,

I posit that this external involvement, whether clandestine, covert. Or overt, drives not only the mobilization and politicization of the no-core group's identity, but also the host state's perception of the non-core group and the state's nation-building policies toward that group. Hence the foreign policy goals of the host state and its interstate relations with external powers drive a host state's choices of nation-building policies towards noon-core groups..$^{50}$

Mylonas also argues that consolidated democracies can afford to accommodate rather than exclude, repress, or attack non-core groups, e.g. the Crimean Tatars, because they are members of extended alliances that reduce their perception of threat and offer them resources with which to deal with such challenges. ${ }^{51}$ Russia lacks such an alliance system and can hardly be called a consolidated democracy as conversely it is more likely to incline towards repressive or even exclusionary policies towards non-core groups. In addition, non-core groups whose homeland lies outside the host state (arguably Crimea is actually part of Ukraine which formally it remains part of) are more likely to become ethnically mobilized against the host state..$^{2}$

Other factors outlined by Mylonas also argue for the enhanced likelihood of Russian repression or exclusion of the Tatars. First, given the nature of the Russian state, a democratically driven policy of accommodation seems almost inconceivable. Moreover, given the inherently coercive predisposition of the state as suggested by Douglas North, John Joseph Wallis, and Barry Weingast in their reflections on the inherent presence of violence in limited access states, even a policy of assimilation primarily utilizing state-driven socioeconomic tools will come to be seen as a coercive forceful, even violent one even if it is not actually coercive. In addition, Mylonas also argues that states pursuing revisionist goals in international affairs like Russia are more likely to pursue exclusionary policies to prevent a "fifth column" at home but these policies are 
inherently risky and could even lead to war. Georgia in 2006-08 and Ukraine in 2014 both confirm this insight..$^{53}$

\title{
The New Repression
}

The forcible return to Russian rule is utterly at odds with the desires of the Crimean Tatars and their leadership expressed in their Majlis (Legislative Council). As the veteran Tatar leader Mustafa Dzhemilyev has said, they want only autonomy within Ukraine, an insight based on the clear recognition that only in a democratic Ukraine - which has now become possible, especially in the light of planned reforms to decentralize Ukraine's administration-is there any hope for the Tatars to obtain any redress of their past grievances. ${ }^{54}$ Not surprisingly they therefore opposed the Russian annexation form the start. Indeed, the Tatar leader, Ilmi Umerov, head of the State Administration in Bakhchysarai in the Crimea, even called the March 2014 and annexation illegal (which they plainly are) and threatened an underground partisan movement. ${ }^{55}$

But even if that had not been their consistent position, it is quite unlikely, given current Russian politics, that they would encounter anything but repression from Moscow. First of all, Russia is still unwilling to face up to the truth of the Stalinist period as a whole, let alone the many deportations including that of the Crimean Tatars. Thus the Russian government has blocked release of a film describing the horrors of the Chechen deportation earlier in $1944 .{ }^{56}$ Accordingly it is no surprise that repression and the visible unwillingness to fulfill guarantees and promises made to them came very quickly. For example, before the March 2014 referendum in Crimea the local authorities led by Moscow's satrap, Sergei Aksyonov, the "Acting Governor," promised them national quotas in the government only to revoke those promises. ${ }^{57}$ On March 19, 2014 Crimean Deputy Prime Minister Rustam Temirgaliyev told the Russian media that the new Crimean Parliament wanted the Tatars to relocate. He said Moscow was ready to pay and help with the moves. ${ }^{58}$ Two weeks later the Crimean Parliament repudiated the deal on national quotas cited above as well as concurrent promises on the Tatars having the right to national and cultural autonomy. ${ }^{59}$

Originally Russia, during March 2014, made many overtures to the Crimean Tatars:

\begin{abstract}
After Refat Chubarov, chairman of the Crimean Tatar Majlis, called on the Crimean Tatars and other residents of Crimea to boycott the referendum, the Crimean parliament on March 11th adopted a declaration "On guarantees for the restoration of rights of the Crimean Tatar people." The declaration stated that in a future Crimean constitution, the Crimean Tatar language will be given the status of official language (together with Russian and Ukrainian), that in executive organs of state power in Crimea at least 20 percent of positions will be reserved for Crimean Tatars, that Crimean Tatar self-government organs, the Kurultai and the Majlis, will be officially recognized, and that financial assistance, as well as assistance for the restoration of historical monuments and native language education, will be provided. Mustafa Dzhemilyev, the former head of the Majlis and the informal leader of the Crimean Tatars, was also invited to Russia, officially by the president of Tatarstan. While there, Vladimir Putin spoke with Dzhemilyev on the phone and reportedly promised "to do everything" to protect Crimean Tatars from any possible aggression. Several official delegations from Tatarstan also visited Crimea and offered material assistance to the Crimea Tatars, many of whom still lack adequate housing after returning from places of deportation. ${ }^{60}$
\end{abstract}

But clearly these were purely tactical gestures and they evoked no support from the Crimean Tatars. By April both local and central indications were clear. The new Crimean constitution proclaimed Crimea "united and indivisible" did not recognize the Crimean Tatars as an "indigenous people" of Crimea and did not give them the right to self-determination or recognize the Majlis or other self-governing bodies. Thus they got no autonomy at all. ${ }^{61}$ The Constitution gave the Tatars Russian citizenship entailing the right to own land and recognized their language as one of Crimea's official languages, but also reduced the total number of Parliamentary seats form 100 to 75, raised the number of single-seat constituencies to 75 percent, and effectively barred the Majlis from fielding party lists because only national, not local or ethnic, parties can compete in Russian elections. ${ }^{62}$ 
Moscow also is trying to eliminate the Tatars' pro-Ukrainian Majlis leadership and split the Tatars' religious administration by creating its own pro-Moscow authorities, both of them being long-standing Muscovite, Tsarist, and Soviet tactics. ${ }^{63}$ At the same time Russia seeks to eradicate any Crimean Tatar Islamist groups and to use its designated strongman in Chechnya, Ramzan Kadyrov, to help control the Tatars. ${ }^{64}$ By late April Moscow and the Crimean authorities exiled Dzhemilyev from Crimea. They threatened him and anyone demonstrating on behalf of Crimean Tatar autonomy in Ukraine with the full weight of repression under Russian law. ${ }^{65}$

Russian repressions did not only occur in this domain. Beyond exiling Tatar leaders, attempting to deprive them of a political voice and to subordinate them wholly to Moscow while breaking earlier pledges, Russian and Crimean authorities also began arresting or worse dissidents, of course not only Tatars. A series of so called "disappearances" began in mid-March finally leading the Crimean Muftiate also known as the Muslim Spiritual Directorate (MSD) to speak out against the authorities. ${ }^{66}$ Moscow, in classic Russian imperialist style, also simultaneously sought to break the ties between the Mufti and the MSD on the one hand and the Majlis on the other. Russian authorities warned that he MSD was "in danger" because of those links to the anti-Russian and anti-Orthodox Majlis. ${ }^{67}$ By the end of June the same official who made this warning, Roman Silantyev a notorious anti-Muslim, warned that the FSB planned to liquidate "radical Islamic organizations in Crimea." Since Silantyev defines as extremist anyone who the authorities do not like and has repeatedly threatened the MSD, this new warning could clearly presage a full-scale offensive on the MSD and the Crimean Tatars. ${ }^{68}$ Finally in early July the Crimean authorities barred Refat Chubarov, leader of the Majlis, from entering "Russian territory" because of his "activities to incite interethnic hatred." In classic Soviet style Crimean authorities said that Chubarov's activities showed he wanted to be exiled from Crimea and deliberately aimed for this outcome. ${ }^{69}$ In the light of Putin's warning that "none of us can allow the Crimean Tatar people to become a bargaining chip in disputesespecially in disputes between Russia and Ukraine," it is clear that they can hope for nothing from either Moscow or the local authorities. ${ }^{70}$ Likewise the UN High Commissioner for human rights, Navi Pillay, stated that "Tatars faced numerous problems including physical harassment, fear of religious persecution and internal displacement." 71 And the UN simultaneously released a report attesting to those risks.

Perhaps most dangerously, it already appears that policies are in train to seize the Tatars' land on which they are living. As Eric Lohr has written,

The Crimean Tatars who have returned from exile in the past 25 years have for the most part not acquired legal title to the properties and land that they have been using. Part of this was a result of the murky status of property after the collapse of the Soviet Union. The Ukrainian authorities failed to resolve the question, and now it stands as a threatening problem for the Tatars. Crimean Deputy Prime Minister Rustam Temirgaliyev recently announced that the government would ask Tatars to vacate "illegally occupied land." This would threaten the status of many of the Tatars, most of whom settled in makeshift homes on unauthorized property when they returned from exile. ${ }^{72}$

Temirgaliyev essentially offered transfers of the Crimean Tatars to other lands but clearly is not interested in resolving claims to the lands from which they were dispossessed in $1944 .{ }^{73}$ Neither can anyone place any credence in his "promises" to resettle the Tatars on suitable lands elsewhere in Crimea.

By June Russia's Ministry of Development was preparing legislation allowing Moscow to seize significant amounts of land in Crimea on an accelerated basis ostensibly to promote economic development along the same lines Moscow used to seize lands in and around Sochi before the Winter Olympics. This economic development would likely take the form of casinos to reduce the costs of annexation by effectively imposing a hidden tax through that sector. Whatever Moscow's motives might be,

The use of the government's power of eminent domain to seize land and then "quietly" privatized it can be sued to change the face of Crimea. It is not difficult to imagine that such 
new powers will be used for Russians with close ties to Moscow and against groups like the Crimean Tatars which oppose the annexation. ${ }^{74}$

Other analyses confirm that due to the incomplete nature of claims of title to land in Crimea "Russian officials will deal with the law much as the Kremlin did with Ukraine's sovereign borders - as they choose." 75

Since the spring of 2014 repression of Crimean Tatar media has continued through processes whereby Moscow has placed them under political and financial pressure. ${ }^{76}$ Similarly, new arrests of leading Crimean personalities, e.g. Akhtem Chyhoz, Deputy Head of the Mejlis, and expulsions from Crimea of Dzhemilev and Chubarov have taken place. ${ }^{77}$ According to Michael Birnbaum of the Washington Post, as of November 2014,

Russian security forces have searched the homes of leaders of the Muslim minority group for banned books. Young Tatar men have been kidnapped off Crimean streets. Tatar activists are sitting in jail. A few have been killed. Some Tatars say they now fear to venture out of their houses. Eight months after Russia annexed the Black Sea resort region of Crimea, the descendants of the group that ruled the peninsula for centuries say they fear a new effort to divide them. Their top leaders are in exile in Kiev. Those who remain say the new Russian authorities in Crimea have spent more time investigating them than the kidnappings. Analysts say Russian security services appear to be employing tactics they have used against Islamist insurgencies within their borders. The difference in Crimea, Tatar leaders say, is that there is no insurgency. But they fear that the tough approach may radicalize the most disaffected members of their community. ${ }^{78}$

Finally, in January 2015, Moscow announced that the trial of Dzhemilev's imprisoned son, Khaizer Dzhemilev, is about to take place despite this being a violation of the provisions of the European Court of Human Rights. ${ }^{79}$

These repressions, as Birnbaum suggests, are hallmarks of classic Russian repressions of the past and-taken in tandem with the ever more overt participation of the Russian military and government in the invasion of Ukraine, and in the commission of what can only be described as acts of terrorism against the local population there - can only arouse the deepest fears that if Russia can continue to act with impunity, the outcome could follow the sanguinary traditions of Russian history.

\section{Turkey and the Chances for Resistance}

Under the circumstances and given the historical connection between the Crimean Tatars and Turkey it is no surprise that the Tatars, increasingly frustrated by this religious, economic, and political repression, as well as the efforts to impose economic and political pressures upon the Tatars' media, have appealed to Turkey and even Azerbaijan for relief and support. ${ }^{80}$ Turkey's $^{\prime}$ position on the annexation of Crimea and the overall Ukrainian crisis has been evolving steadily towards greater resistance and opposition to Moscow's actions and claims. Cemil Cicek, Speaker of Turkey's Parliament, recently denounced the annexation of Crimea as unacceptable and that Turkey would not recognize it and instead give priority to the support of the Tatars. ${ }^{81}$ Similarly when the crisis began Prime Minister Erdogan said he had urged Putin to respect the rights of the Tatars. ${ }^{82}$ In early July Foreign Minister Akhmet Davutoglu received Dzhemilyev and Chubarov, denounced the barriers to their returning to Crimea, and stated that Turkey was not wavering in its support for the Crimean Tatars despite its close economic and political ties with Russia. ${ }^{83}$ Indeed, Turkey has now banned any ship form its harbors that declares that they have passed through a Crimean port identified as part of the Russian Federation, or that they are from those ports. $^{84}$

Nevertheless, both Ankara and Baku have multiple reasons for caution in defending the Crimean Tatars as more overt representations on their behalf would not only jeopardize their own ties to Moscow but also go far to confirm the visible suspicions of both local and central authorities in Crimea and Russia that the Tatars are a seditious "fifth column" with ties to Turkey and plotting 
to embroil Turkey and Azerbaijan in Russia's internal affairs. The many signs of this mentality of suspicion, coupled with the fact that for twenty years Russian nationalism has been systematically directed against Muslims, can only add to the angers facing the Crimean Tatars ${ }^{85}$

\section{Conclusions}

Thus we have, in a sense, returned full circle to the past whereby repression at home begets suspicions not only of disloyalty but of active connivance with foreign powers in anti-Russian (or anti-Soviet) activities that only further add to the motives of imperial greed, concentration of power, and chauvinism to facilitate policies ending in deportation. But it is not only the foreign dimensions of Russian nationality policies that evoke the past. The overall domestic and nationality policies of the Russian regime betray an addiction to the past disasters of Russian history, suggesting that in some sense Russia is what Claude Levi-Strauss called a frozen culture. The return of official nationality and the mounting evidence of officially inspired ethnic hatreds and toleration for locally generated manifestations of these emotions also evoke previous manifestations of these phenomena throughout the entire span of Russian history.

We may fairly say that today no institutional, moral, or legal barriers other than expediency and potential fear of the consequences stand between the Kremlin and the orchestration of another deportation of an ethnic or other minority that is deemed to be a threat to the government. But today, unlike in the past, Muslims are now considered as insurgents all over the world, including the North Caucasus. There are plenty of signs that Russian repression could generate an Islamic or other terrorist movement among Crimean Tatars that could ultimately connect with those in the North Caucasus. And there is no reason to believe that the Kremlin is not concerned that this could come about. ${ }^{86}$ Even before this crisis there was a high potential for violence in Crimea and analysts who studied it worried that the conventional wisdom was that Russia could annex it and was thinking of doing so whenever that decision suited it. ${ }^{87}$ Yet the potential for ethnic violence has been there from 1991 and Russian policies are clearly, just as in the North Caucasus, stimulating that potential outcome. Pace Naimark and Brecht, the forces that made for past deportations could come again, and not only against the Crimean Tatars for it is clear that overall nationality policy is moving towards ever stricter centralization, repression, chauvinism, etc. as in the past. But this time the spirit of resistance pervades the Muslim world and they will fight back. Moscow may believe, as St. Petersburg did a century ago, that it could incite ethnic antagonisms in the Black Sea basin and benefit from doing so even at the cost of war. ${ }^{88}$ But that illusion was brutally shattered in the First World War and an equally delusional drive to restore the empire to save Putinism could trigger one or more new theaters in the global war on terror. Right now Putin seems to resemble Nicholas I in his policies, not least in the return of official nationality. ${ }^{89}$ But as one Russian historian observed afterwards, all that one could say about Nicholas I's reign was that "it all was a mistake." That mistake ended in the Crimean war that set Russia on the path of failed renewals and abortive efforts to coerce and even deport Russia's ethnic minorities, leading to its ultimate destruction under the ill-fated and equally, albeit differently, misguided Nicholas II. If Russia continues as it is going towards the Crimean Tatars and the other ethnic minorities of Russia, Putin might yet come to be seen not as the heir of the "iron Tsar" but of his feckless great-grandson.

\section{Endnotes}

1 Norman Naimark, Fires of Hatred: Ethnic Cleansing in Twentieth Century Europe (Cambridge, MA and London: Harvard University Press, 2001), p. 107.

2 Carol Weaver, The Politics of the Black Sea Region: EU Neighbourhood, Conflict Zone or Future Security Community (London: Ashgate Publishers, 2013), p. 135.

3 Nicholas V. Riasanovsky, Nicholas I and Official Nationality in Russia 1825-1855 (Berkeley and Los Angeles: University of California Press, 1959).

4 Tom Malinowski, "Behind Putin's Cynicism and Hypocrisy," Wall Street Journal, May 18, 2014, http:// www.wss.com; Semih Idiz, "Erdogan Under Pressure Over Threat to Tatars in Ukraine," http://www.almonitor.com, May 19, 2014.

5 Gregory Stanton, "The Eight Stages of Genocide," in The Genocide Studies Reader, eds. Samuel Totten and Paul Bartrop (London: Routledge, 2008), 127-129. 
6 Tom Malinowski, "Behind Putin's Cynicism and Hypocrisy," Wall Street Journal, May 18, 2014, http:// www.wss.com; Semih Idiz, "Erdogan Under Pressure Over Threat to Tatars in Ukraine,' http://www.almonitor.com, May 19, 2014

7 Norman Naimark, Stalin's Genocides (Princeton, NJ: Princeton University Press, 2010); Timothy Snyder, Bloodlands: Europe Between Hitler and Snyder (New York: Basic Books, 2010).

8 Walter Richmond, The Circassian Genocide (New Brunswick: Rutgers University Press, 2013).

9 Douglas Irvin-Erickson, "Genocide, The 'Family of Mind,' and The Romantic Signature of Raphael Lemkin," Journal of Genocide Research 15, 3 (2014): 273-296. http://dx.doi.org/10.1080/14623528.2013.821222/.

10 Ibid.

11 Terry Martin, “The Origins of Soviet Ethnic Cleansing," Journal of Modern History, 70, 4 (1998): 815-860. http://dx.doi.org/10.1086/235168.

12 Ibid., pp. 813-860

13 Ibid., p. 822

14 Raphael Lemkin, Axis Rule in Occupied Europe: Laws of Occupation, Analysis of Government, Proposals for Redress (Washington, D.C.: Carnegie Endowment for International Peace, 1944), 79.

15 Daniel Feierstein, Genocide as Social Practice: Reorganizing Society under the Nazis and Argentina's Military Juntas. Douglas Andrew Town, trans. (New Brunswick: Rutgers University Press, 2014).

16 Naimark, Fires of Hatred, 106-107

17 Joshua Kucera, “European Court of Human Rights Rules against Russia for Expulsions of Georgians,” Eurasian Insight, July 7, 2014, http://www.eurasianet.org

18 On the nature of the state and its resemblances to past Russian states see, Richard Hellie, "The Structure of Russian Imperial History," History and Theory, 44, 4 (2005): 88-112; Peter Baker and Susan Glasser, Kremlin Rising: Vladimir Putin's Russia and the End of Revolution (New York: Scribner's: 2005), 417; Steven Rosefielde, Russia in the $21^{\text {st }}$ Century: the Prodigal Superpower (Cambridge: Cambridge University Press, 2004); Marshall T. Poe, The Russian Moment in World History (Princeton, NJ: Princeton University Press, 2003); Stefan Hedlund, Russian Path Dependence (London: Routledge, 2005); Emil Pain, "Will Russia Transform Into a Nationalist Empire," Russia in Global Affairs, 3, 2 (2005): 71-80; Stephen Kotkin, "It's Gogol Again," Paper Presented as part of the project The Energy Dimension in Russian Global Strategy, James A. Baker III Institute for Public Policy, Rice University, Houston, Texas, United States. These are only a few of the authors who now see the vitality of the Tsarist metaphor as a means of explaining Putin's Russia; Center for Strategic and International Studies (Washington, D.C.: Praeger, 2004) passim; Richard Pipes, Russia Under the Old Regime (New York: Scribner's 1975); Stephen Blank, Rosoboroneksport; Its Place in Russian Defense and Arms Sales Policy (Carlisle Barracks, PA: Strategic Studies Institute, US Army War College, 2007); Harley Balzer, "Confronting the Global Economy After Communism: Russia and China Compared," Paper Presented to the Annual Convention of the International Studies Association, Honolulu, Hawaii, March 1-5, 2005.

19 Douglass C. North, John Joseph Wallis, Barry R. Weingast, Violence and Social Orders: A Conceptual Framework for Interpreting Recorded Human History (Cambridge: Cambridge University Press, 2009). http:// dx.doi.org/10.1017/CBO9780511575839.

20 Frank Umbach, “Energy: Cheap Russian Gas Deal Undermines Ukraine's Energy Strategy,” Geopolitical Information Service, February 24, 2014, 2.

21 Ibid.; “Gazprom Seeks Access to Crimean Oil and Gas Deposits," March 18, 2014, http://en.ria.ru/ $\underline{\text { russia/20140319/188548112/Gazprom-Seeks-Access-to-Crimean-Oil-and-Gas-Deposits.html }}$

22 Daron Acemoglu and James A. Robinson, Why Nations Fail: The Origins of Power, Prosperity, and Poverty (New York Crown Business Books, 2012).

23 Alexander Etkind, Internal Colonization: Russia's Imperial Experience (London: Polity Press, 2011).

24 Maurice Friedberg, Russian Culture in the 1980s, Significant Issues Series (Washington, D.C.: Center for Strategic and International Studies, 1985).

25 Pierre Hassner, “Russia's Transition to Autocracy,” Journal of Democracy 19, 2 (2008), 7.

26 Ibid., 9-10

27 Alexander J. Motyl, “Surviving Russia's Drift Towards Fascism,” Kyiv Post, January 17, 2008; Alexander J. Motyl, "Inside Track: Is Putin's Russia Fascist,?" The National Interest, December 3, 2007, http://www. nationalinterest.org; Victor Yasmann, "Russia: Putin's Plan To Become 'Father of a New Country,"' Radio Liberty Radio Free Europe Features, December 20, 2007; Stephen Blank, "Russia's Lurch Toward Fascism," http://www.huffingtonpost.com/stephen-blank/russias-lurch-toward-fasc b 5169230.html, April 18, 2014. 
28 Alexander J. Motyl, “Inside Track: Is Putin's Russia Fascist?” The National Interest, December 3, 2007, http:// www.nationalinterest.org.

29 Ibid.

30 Schumpeter's quote is from the 1947 edition of his famous work, Capitalism, Socialism, and Democracy and is quoted in Marcel H. Van Herpen, Putin's Wars: The Rise of Russia's New Imperialism (Lanham and Boulder: Rowman and Littlefield, 2014), 41.

31 Aurélie Campana, "Sürgün: The Crimean Tatars' Deportation and Exile," Online Encyclopedia of Mass Violence, [online], published on 16 June 2008, accessed 31 January 2015, URL: http://www.massviolence. org/Surgun-The-Crimean-Tatars-deportation-and-exile, ISSN 1961-9898.

32 Norman Naimark, Fires of Hatred, 105.

33 “Address by President of the Russian Federation," March 18, 2014, http://eng.kremlin.ru/transcripts/6889.

34 "Address by President of the Russian Federation," March 18, 2014, http://eng.kremlin.ru/transcripts/6889.

35 Federal'nyi Zakon Rossiiskoi Federatsii Ot 28 Dekabria 2013 God N433-03 “O Vnesenii Izmeneniia v Uglovnyi Kodeks Rossiiskoi Federatsii," Rossiyskaya Gazeta, December 30, 2013, http://www.rg.ru/ printable/2013/12/30/uk-izm-dok; "Speech at Gala Concert To Mark the 69th Anniversary of Victory In the Great Patriotic War and 70th Anniversary Of the Liberation of Sevastopol From Nazis, http://www. kremlin.ru, May 9, 2014, http://eng.kremlin.ru/transcripts/7159.

36 Federal'nyi Zakon.

37 Harris Mylonas, The Politics of Nation-Building: Making Co-Nationals, Refugees, and Minorities (Cambridge: Cambridge University Press, 2012); Michael A. Reynolds, Shattering Empires: The Clash and Collapse of the Ottoman and Russian Empires, 1908-1918 (Cambridge: Cambridge University Press, 2011).

38 Ahto Lobjaskas, “Eastern Partnership-The EU's Accidental Sphere of Influence," Radio Free Europe Radio Liberty, May 7, 2009, http://www.rferl.org.

39 Matthew Sussex, ed., Conflict in the Former USSR (Cambridge, Cambridge University Press, 2012); Emil Souleimanov, Understanding Ethnopolitical Conflict; Karabakh, South Ossetia, and Abkhazia Wars Reconsidered, "Foreword," Stephen Blank (New York: Palgrave Macmillan, 2013).

40 Mary Kaldor, New \& Old Wars: Organized Violence in a Global Era (Stanford: Stanford University Press, 1999). 41 Martin, p. 829; Reynolds, passim.

42 Martin, p. 829.

43 Reynolds; Martin, pp. 813-60; Mylonas.

44 "Interview with Sergei Rogov by Vadim Solovyev," Moscow, Nezavisimaya Gazeta Online, in Russia, April 2, 2009, FBIS SOV, April 2, 2009.

45 Elizabeth Wishnick, "The Securitization of Chinese Migration to the Russian Far East: Rhetoric and Reality," Paper Presented at the Annual Meeting of the International Studies Association, Hilton Hawaiian Village, Honolulu, Hawaii, March 2005; Kristian Atland and Kristin Van Bruusgaard, "When Security Speech Acts Misfire: Russia and the Elektron Incident," Security Dialogue, 40, 3 (2009): 335-336.

46 Edwin Bacon and Bettina Renz with Julian Cooper, Securitizing Russia: The Domestic Politics of Russia (Manchester: Manchester University Press, 2006), 10-11.

47 Kristian Atland and Torbjorn Pedersen, "The Svalbard Archipelago in Russian Security Policy: Overcoming the Legacy of Fear-Or Reproducing It?" European Security, 17, 2-3 (2008): 230-231.

48 Martin, pp. 813-60; Reynolds, 261-262.

49 Ibid., Naimark, Fires of Hatred, 103-104.

50 Mylonas, p. 5.

51 Ibid., p. 8.

52 Ibid., p. 21.

53 Ibid, p. 42.

54 Kyiv. 5 Kanal TV, in Ukrainian Open Source Center Foreign Broadcast Information Service, Central Eurasia, (Henceforth FBIS SOV), July 5, 2014.

55 Graham, Stack, "Crimean Tatar Head Threatens Partisan Movement If Russia Annexes," Business New Europe, March 11, 2014, http://www.bne.eu/story/5848.

56 Maribek Vatchagaev, “Controversy Emerges Inside Russia Over Chechen Film Depicting 1944 Deportations," Eurasia Daily Monitor, June 20, 2014.

57 Moscow, Gazeta.ru, in Russian, May 19, 2014, FBIS SOV, May 22, 2014.

58 "Putin Promises to Consider Rehabilitation of Crimean Tatars," http://www.breitbart.com, April 2, 2014, http:// www.breitbart.com/Big-Peace/2014/04/02/Putin-Promises-to-Consider-Rehabilitation-of-Crimean-Tatars. 
59 Ibid; "Russia: Strategy to Deal With Crimean Tatars Marginalizes Group, Backs New Leaders," Open Source Center, Analysis, May 30, 2014.

60 Oxana Shevel, “To Strengthen Claims On Crimea, Russia and Ukraine Woo Crimean Tatars," The Washington Post, March 25, 2014, http://www.washingtonpost.com/blogs/monkey-cage/wp/2014/03/25/to-strengthenclaims-on-crimea-russia-and-ukraine-woo-crimean-tatars/. Refat Chubarov's statement to boycott the referendum can be found at the following site: http://crimea24.info/2014/03/06/krymskie-tatary-prinyalireshenie-bojjkotirovat-referendum-separatistov/; The declaration adopted by the Crimean parliament on March 11th can be found at the following site: http://news.allcrimea.net/news/2014/3/11/parlament-krymaprinyal-postanovlenie-o-garantiyah-vosstanovleniya-prav-krymskotatarskogo-naroda-7158/.

61 "Russia: Strategy to Deal With Crimean Tatars Marginalizes Group, Backs New Leaders."

62 Ibid.

63 Ibid.

64 Ibid.

65 Idil P. Izmirli, "Crimean and Russian Authorities Ban Leader of Crimean Tatars Fpm His Homeland," Eurasia Daily Monitor, April 28, 2014; Idil P. Izmirli, “Mustafa Cemilev's Personality Inspires Crimean Tatars to Resist Harassment From Russian Authorities," Eurasia Daily Monitor, May 9, 2014," "Russia to Crimean Tatars: You're Either With Us, Or Against Us," Eurasia Insight, May 6, 2014, http://www.eurasianet.org.

66 Paul Goble, "Window on Eurasia: Crimean Muftiate Speaks Out As Russian Occupiers Ignore Crimean Tatars," June 12, 2014.

67 Paul Goble, "Window on Eurasia: Moscow Trying to Force Crimean MSD to Break With Crimean Tatars," May 22, 2014.

68 Paul Goble, Window on Eurasia: "FSB Preparing to close Muslim Institutions in Occupied Crimea, Silantyev Says," June 30, 2014.

69 Moscow, RIA Novosti, In Russian, July 6, 2014, FBIS SOV, July 6, 2014; Paul Goble, Window on Eurasia: "Russian Occupiers Block Another Crimean Tatar Leader From Returning to His Homeland," July 6, 2014; “Russia Bars Second Tatar Leader From Entering Crimea," Radio Free Europe Radio Liberty, July 7, 2014.

70 Denis Dyomkin and Alexander Winning, “Crimean Tatars Condemn Ban on Rally to Mark Stalin's Persecution," Reuters, May 16, 2014, http://www.reuters.com/article/2014/05/16/us-ukraine-crisis-crimeatatars-idUSBREA4F0LS20140516.

71 AlecLuhn, “VladimirPutinTellstheCrimea'sTatarsTheirFutureLiesWithRussia,” TheGuardian,May16,2014, http://www.theguardian.com.

72 Eric Lohr, "Russia and the Crimean Tatars: the Burden of History," Religion \& Politics, May 28, 2014, http://relionandpolitics.org.

73 “Crimean Tatars Will Have to Vacate Land-Official," RIA Novosti, March 19, 2014, http://www.en.ria.ru.

74 Paul Goble, Window on Eurasia: "Moscow Preparing to Seize Land in Crimea For 'State Needs" as It Did In Sochi," June 14, 2014.

75 Human Rights in Ukraine, Information Website of the Kharkov Human rights Protection Group, "Moscow's Special Economic zone' Could Dispossess Crimeans," http://www.khpg.org, June 11, 2014.

76 Open Source Center Media Aid, Crimean Tatar Media Outlets Under Political Financial Pressure, July 7, 2014.

77 Halya Coynash, “Crimean Tatar Leader Arrested In New Wave of Repression,” Human Rights in Ukraine, http://www.khpg.org/en/index.php?id=1422581395, January 30, 2015.

78 Michael Birnbaum, “Crimean Tatars Say Russian Annexation Has Brought Fear and Repression All Over Again," Washington Post, November 30, 2014, http://www.washingtonpost.com/world/europe/crimeantatars-say-russian-annexation-has-brought-fear-and-repression-all-over-again/2014/11/28/c2a3bcea-73ed11e4-95a8-fe0b46e8751a story.html.

79 “Trial In Russia Imminent of Mustafa Dzhemiliev's Hostage Son,” http://www.khpg.org/en/index. php?id=1422476041, January 30, 2015.

80 “Krmskie Tatary Upovayut na Aliyeva i Erdogana," http://www.haqqin.az, July 4, 2014.

81 Ankara, Anadolu Agency Online, in English, June 13, 2014, FBIS SOV, June 13, 2014; Giorgi Lomsadze, “Crimean Tatars Ask Azerbaijan's Ilham Aliyev For Help," Eurasia Insight, March 10, 2014, http://www. eurasianet.org.

82 Marina Koren, “Why Turkey Is Getting Involved in Ukraine,” http://www.naitonaljournal.com, March 10, 2014. 
83 “MID Turtsii Prizval Izmenit' Politiku v Otnoshenii Krymskikh Tatar,” http://www.qha.com July 8, 2014.

84 Paul Goble, Window on Eurasia: “Turkey Will 'Always Stand With Crimean Tatars,' Ankara Says," July, 8, 2014.

85 Lohr, "Russia and the Crimean Tatars: the Burden of History."

86 American Center for Democracy blog, “New Calls for Jihad Against Russia,” May 27, 2014; Maribek Vachtagaev, "Will Crimean Tatar Jihadists Join Forces With the Caucasus Emirate?" Eurasia Daily Monitor, May 22, 2014.

87 William Varretoni, “Crimea's Overlooked Instability," The Washington Quarterly, 34, 3 (2011): 87-99. http:// dx.doi.org/10.1080/0163660X.2011.588128.

88 Reynolds, Shattering Empires.

89 Paul Kubicek, "Nationalism and Legitimation For Authoritarianism: A Comparison Of Nicholas I and Vladimir Putin," Journal of Eurasian Studies 5, 1 (2014): 1-9. http://dx.doi.org/10.1016/j.euras.2013.11.001. 